\title{
ETNOGRAFIA DO ETNÓGRAFO
}

\section{Vinicius Esperança ${ }^{1}$}

Empreendi, durante a pesquisa de mestrado ${ }^{2}$, uma análise de diferentes formas de ação do estado e seus agentes no conjunto de favelas do Complexo do Alemão, zona norte da cidade do Rio de Janeiro, desde a ocupação do "território" 3 pelo Exército Brasileiro, de novembro de 2010 a junho de 2012, até o primeiro ano de funcionamento das Unidades de Polícia Pacificadora instaladas logo em seguida. O objetivo deste artigo é lançar um olhar sobre as subjetividades envolvidas na construção desta etnografia, assim como sobre a pessoa do etnógrafo como objeto de análise, tanto quanto suas diferentes posições estabelecidas como interlocutor no campo de pesquisa e seus respectivos riscos.

\section{Primeiras aproximações e afastamentos}

Fui espectador das internacionalmente veiculadas imagens da fuga de traficantes da favela vizinha da Vila Cruzeiro para o Complexo do Alemão, mas jamais havia estado no local. $\mathrm{O}$ assunto era bastante debatido nas classes de Licenciatura em Ciências Sociais, do Instituto de Humanidades da Universidade Candido Mendes ${ }^{4}$, onde estava por me formar no ano seguinte. Um colega de turma, pastor evangélico e morador do Complexo, trazia sempre novas notícias sobre os eventos desencadeados desde a ocupação do Exército. Meu interesse pela pesquisa, contudo, só foi despertado no mês de outubro, do ano de 2011, quando precisei entregar trabalho de conclusão da disciplina "Laboratório de Pesquisa Etnográfica", lecionada pelo Prof. Hélio Silva, também meu orientador de monografia. Sem conseguir desenvolver um projeto anterior sobre festas populares, soube por um amigo, capelão militar, que o Exército estaria

\footnotetext{
${ }^{1}$ Universidade Cândido Mendes, Brasil.

${ }^{2}$ Realizado no Programa de Pós-Graduação em Ciências Sociais da Universidade Federal Rural do Rio de Janeiro, defendida a dissertação em abril de 2014, sob a orientação da Profa. Carly Machado.

${ }^{3}$ Reconheço que chamar a região de "território do Complexo do Alemão" pode reforçar a exclusão e a estigmatização históricas daquelas favelas, já que o termo não é usado para tratar de outras regiões da cidade. Por exemplo, fala-se de "região", "jurisdição" e "zona" quando se trata de outras regiões da cidade como Barra da Tijuca, Leblon ou Jacarepaguá. Contudo, já que este trabalho se propõe a analisar a ação do estado e os agentes e instituições do estado se utilizam amplamente do termo, resolvi adotá-lo, sempre entre aspas.

${ }^{4}$ No ano seguinte, tornou-se IUPERJ.
} 
promovendo reuniões com líderes religiosos dos Complexos do Alemão e da Penha. Interessado pela questão, perguntei se poderia participar como observador, sem imaginar os desdobramentos que minha presença naquela primeira reunião teriam, tanto na vida pessoal quanto para minha formação como antropólogo.

Devo a este amigo capelão, a quem devo preservar o nome, e chamar de Tenente Lucio, a enorme facilidade inicial que tive ao entrar no campo. Ele estava envolvido na organização destas reuniões promovidas pelo Exército. Pude acompanhá-lo em diversas visitas a líderes religiosos, a fim de convidá-los a participar das reuniões, assim como estive presente nelas. Fui apresentado como pesquisador, mas meu passado como pastor protestante e formação como teólogo também foram usadas como moeda que facilitou a entrada e ajudou a diminuir a desconfiança histórica que o Exército Brasileiro possui em relação a cientistas sociais. Obtive carta de apresentação da Universidade Candido Mendes, que me apresentava como estudante e pesquisador do tema. Esta carta foi entregue ao Padre Capelão responsável pela condução das reuniões, a quem passo a chamar de Padre Jeferson. Na ocasião, estive em sua sala no Palácio Duque de Caxias ${ }^{5}$. Ele a leu atentamente. Tenente Lucio enfatizou que eu também era teólogo. Fui, então, aceito como pesquisador e autorizado a acompanhar este processo de aproximação do Exército com as redes religiosas locais.

Durante a escrita deste capítulo, lendo textos de Celso Castro, sobre seu trabalho de campo com militares, e recordando eventos passados, especialmente as longas conversas com minha orientadora de mestrado, Profa. Carly Machado, fui acometido por uma avalanche de percepções e insights cuja intensidade e descrição confesso ser pouco talentoso para descrever. Tentarei exemplificar.

No final do ano de 1995, aos quatorze anos de idade, fui a um cinema de shopping center, acompanhado de minha mãe, assistir ao filme americano de suspense “Os Suspeitos” (The Usual Suspects, 1995, de Bryan Singer). Num dos finais-surpresa mais bem construídos do gênero, o personagem do ator Chazz Palminteri, um detetive policial, evoca mentalmente diversos pequenos detalhes de uma narrativa sobre determinado evento criminoso. Numa tempestade de lembranças e associações, descobre que acabara de soltar, provavelmente para nunca mais encontrá-lo, o assassino em série e notório criminoso que motivou toda a investigação e o enredo do filme. $\mathrm{O}$ vilão, que se apresentava como um sujeito coxo e intelectualmente limitado, é desvelado

${ }^{5}$ Prédio de grandes proporções localizado no centro da cidade do Rio de Janeiro, ao lado do terminal ferroviário Central do Brasil, e que abriga o Comando Militar do Leste. 
como o construtor de toda a narrativa que assistimos, e vai embora livre, ajeitando os pés tortos, que agora funcionam perfeitamente, e nos entrega um sorriso vitorioso, que nos faz entender aquilo que parece um grande golpe: a narrativa que nos envolveu por duas horas foi uma construção totalmente enviesada. Senti-me, em parte, como o detetive, quando o fluxo de descobertas o desconcerta e faz com que derrube sua caneca de café 6 e, em parte, como o narrador, que pega a todos de surpresa, "jogando na cara" aquilo que, no fundo, sabemos, mas preferimos ignorar: que a narrativa é uma construção parcial, enviesada e comprometida do seu autor, assim como a etnografia construída pelo antropólogo.

Em Antropologia, pelo menos desde os anos 1960, temos consciência disso, portanto, agora, preciso entregar o jogo. Mesmo que, por algum tempo, tenha acreditado na objetividade parcial da minha narrativa, agora, conscientemente, derrubo a caneca de café e entrego o final da estória antes do início, para que o leitor não se sinta ludibriado, como aqueles que assistiram desavisados ao filme. Em cinema, o recurso valeu um Oscar ao seu roteirista; na Antropologia, valeria uma reprovação ou um lugar empoeirado num canto esquecido onde ficam as etnografias ruins.

Achei que faria tudo errado ao enfrentar esta questão antes do desenvolvimento de outros dentro de uma dissertação. Os manuais mandam fazer o contrário. A ideia de inverter o processo veio da Carly Machado. "Acho que você precisa de uma introdução para conseguir escrever sua dissertação”, disse. Mais de uma vez reclamou que minha escrita estava presa e que eu parecia emocionalmente pouco envolvido no processo de construção do texto. Disse, também, que a qualidade do meu texto dependia do grau de envolvimento emocional que tinha com o processo de construção do mesmo. Sim, ela já havia lido textos meus bem melhores do que aquilo que eu vinha produzindo nos últimos nove meses. Olhei balançando a cabeça e emitindo sons de concordância, enquanto pensava, confuso, sobre onde ela estaria com a cabeça ao dizer isso. Além de lembrar, constantemente, mesmo que não quisesse, que além de antropóloga, ela também era psicóloga.

Pois bem, foi lendo confissões de Celso $\mathrm{Castro}^{7}$, lembrando de muitos filmes, das leituras em Virginia Woolf, Clarice Lispector e James Joyce, e das conversas com a Carly que me vi, numa terça-feira ensolarada de dezembro, trancado no quarto, numa quase overdose de cafeína, fazendo brotar um fluxo de consciência de qualidade

\footnotetext{
${ }^{6} \mathrm{~A}$ minha entornou algumas vezes durante a escrita.

${ }^{7}$ Antropólogo carioca que fez importante trabalho de campo entre militares.
} 
literária duvidosa, mas absolutamente necessário e libertador. Aquilo que se transformou em texto acadêmico como parte de capítulo de uma dissertação de mestrado foi aquilo que tive coragem de mostrar.

\section{Um pouco de reflexividade}

"Saber impor-se é importante para o sucesso de uma pesquisa de campo com militares (...) Isto é, ou você impõe respeito, ou permanece numa posição subordinada" (Castro, 2009, p. 23). Assim o autor reflete sobre o dia em que esteve na presença do general comandante da Academia Militar dos Agulhas Negras, até então pouco receptivo a sua possível entrada no campo. A postura com que o pesquisador se apresentou e dialogou com o general foi, segundo ele, determinante para a autorização de entrada no campo. Não poucas vezes minha orientadora chamou a atenção e pediu para que refletisse sobre aquilo que ela chamava de uma "postura", ou seja, um modo de me apresentar e me conduzir com naturalidade entre locais de poder. Dizia que eu fazia isso com muita facilidade, mas de forma inconsciente. Também não foram poucas as ocasiões em que o amigo capelão, e também posteriormente colega de turma no mestrado, jocosamente, gostava de me irritar me chamando de "pastor", "o mais militar dos civis" e "amigo do exército" 8 . Tudo isso apontava para algo que eu não queria enxergar: a forma camaleônica com que eu conseguia me inserir em diferentes estâncias de poder, ora sem ser notado, ora sendo notado de forma a assumir posições que contribuíam para meus objetivos.

Só consigo enfrentar esta questão com a consciência do quanto o trabalho de campo e meu fazer antropológico devem a minha história de vida e formação como ser humano. Evitarei falar de identidade, já que penso o processo de construção da identidade individual e coletiva como algo fluido, transitório, histórico e pouco fixo. As escolhas da pesquisa e das temáticas; a escolha para onde voltar o olhar e por quais caminhos seguir; as múltiplas interações com os atores do campo; os motivos pelos quais tantas portas se abriram e tantas outras se fecharam; tudo isto é reflexo da subjetividade do antropólogo. Não o antropólogo genérico, abstrato, mas o indivíduo concreto que, consciente de parte de seus vieses e subjetividades, precisa se desnudar para realmente enxergar. Para tanto, nesta introdução, proponho uma antropologia de

${ }^{8}$ Ele identificava uma certa rigidez de método e organização, especialmente com prazos e horários que, segundo ele, se assemelhava a uma disciplina pessoal militarizada. 
cara limpa ou uma antropologia desnudada que tenta estar consciente dos processos mentais que determinam o esculpir etnográfico com todas as suas escolhas, contradições, acertos, equívocos e limitações.

Para além da subjetividade do etnógrafo, espero não perder de vista o papel do acaso e da coincidência. Afinal, esta etnografia e seus apontamentos só existem porque estive em alguns lugares e não em outros; porque me atrasei ou cheguei cedo demais em alguns eventos e lugares; porque decidi ir a determinados lugares e não a outros e a falar com determinadas pessoas; porque fiz escolhas e fui impedido pela contingência a fazer outras. Um dia a menos no campo, entrar por uma rua errada, estar no local errado, falar o que não deveria, vestir-me de forma diferente, tomar o próximo trem, poderiam abrir a possibilidade de que houvesse uma outra etnografia ou até mesmo a ausência dela.

Donna Haraway (1995), em discussão sobre a questão da ciência para o feminismo e o privilégio da perspectiva parcial, foi um alento para minha angustiante jornada em encontrar os loci onde meu subjetivismo ancorado na visão parcial e fragmentada do campo encontraria a produção de um conhecimento "real" e "genuíno" ao qual me dediquei por tanto tempo. A autora propõe o conceito de saberes localizados a fim de construir uma doutrina de objetividade corporificada que acomode os projetos científicos feministas críticos e paradoxais. Insistindo na metáfora da visão, sempre corporificada e particular, sugere que isto permite construir uma doutrina da objetividade. Nossos olhos são sistemas de percepção ativos que constroem e desconstroem modos específicos de ver e traduzir.

\footnotetext{
"Precisamos aprender em nossos corpos, dotados das cores e da visão estereoscópica dos primatas, como vincular o objetivo aos nossos instrumentos teóricos e políticos de modo a nomear onde estamos e onde não estamos, nas dimensões do espaço mental e físico que mal sabemos como nomear. Assim, de modo não muito perverso, a objetividade revela-se como algo que diz respeito à corporificação específica e particular e não, definitivamente, como algo a respeito da falsa visão que promete transcendência de todos os limites e responsabilidades. A moral é simples: apenas a perspectiva parcial promete visão objetiva.” (Haraway, 1995, p. 21)
}

Esta objetividade feminista trata de conhecimentos e localizações limitados, não da transcendência e divisão entre sujeito e objeto das narrativas culturais ocidentais. Assim, para Haraway, podemos nos tornar responsáveis por aquilo que aprendemos a ver. Embora meu texto não possa ser enquadrado na categoria de texto feminista, esta pesquisa se esforça no caminho da construção de um conhecimento corporificado, 
localizado, sempre parcial e, portanto, responsável e pronto a prestar contas de suas ambiguidades, (des)caminhos e posições.

Para não dizer que não falei de gênero e outros marcadores de diferença, certos fatores devem ser levados em conta: Sou homem e tive entre 30 e 32 anos enquanto fazia o trabalho de campo. Isto só é dito porque acredito que estes fatores, de alguma forma, foram determinantes para a realização da pesquisa. Cada um deles seria percebido de forma muito mais marcada se eu não me visse e fosse visto com/como aquilo que acima descrevi. Ser homem facilitou a entrada e a aproximação em instituições marcadas pela "masculinidade" e "virilidade". Ter a idade que tinha evitou alguma possível resistência nestas instituições, especialmente entre os de mais alto escalão. Não me sinto capaz de discorrer nem problematizar se o fato de ser branco foi determinante para o trabalho de campo. Provavelmente, foi, mas não tenho o fôlego para problematizar este aspecto nesta pesquisa.

\section{Riscos da pesquisa}

Corri inúmeros riscos e não sei se saio ileso de todas as armadilhas que se configuraram durante o trabalho de campo e da construção do texto etnográfico. Os riscos apresentaram-se no comprometimento da qualidade/responsabilidade do trabalho, assim como a própria integridade física do pesquisador.

\section{A pesquisa entre militares}

Quanto ao primeiro aspecto, destaco alguns tópicos que considero importantes:

Durante a pesquisa com militares fui, por diversas vezes, convidado, de forma até mesmo sedutora, a assumir o ponto de vista que possuíam sobre a ocupação militar naquele território. Tive, pelo menos, três longas conversas com um dos generais responsável pelas tropas. Este havia vindo do Haiti e definitivamente não se encaixava no estereótipo negativo que eu havia construído mentalmente sobre como deveria ser um general: velho, autoritário e rígido. Relativamente jovem- com menos de cinquenta anos- simpático e de boa aparência, além de transmitir grande entusiasmo e aparente sensibilidade pelos moradores atendidos. Fui bem recebido, almocei por duas vezes na 
mesa dos oficiais de comando e, logo, cooptado para produzir conhecimento útil para o exército.

Numa das reuniões com líderes religiosos, as quais serão descritas e analisadas no terceiro capítulo, avisaram-me que o general ficou sabendo da presença de um pesquisador e gostaria de me conhecer. A conversa se deu na presença do capelão Lúcio. O general discorreu sobre sua experiência no Haiti e explicitou alguns planos de assistência social que seu comando tinha na região dos Complexos do Alemão e da Penha. Nesta conversa, foi-me solicitado, como pesquisador ${ }^{9}$, e alguém ligado à universidade, e que não possuía vinculação política com qualquer ONG local, partido político ou associação de moradores, a atuação como um dos interlocutores entre as demandas sociais da favela e as possíveis ações que o exército poderia implementar enquanto lá estivesse. A principal forma de atuação seria na produção de conhecimento, identificando, para o exército, quais seriam as principais necessidades da região e de que forma o exército poderia atuar sobre elas ${ }^{10}$. Eu seria o braço civil e o capelão Lúcio o braço religioso-militar.

Produzi dois documentos que foram entregues ao General e que circularam entre outros oficiais. O primeiro foi um artigo intitulado "Favela, Exército e Religião", que trazia as primeiras impressões e análises das primeiras semanas de campo. O segundo, este verdadeiramente encomendado no prazo de uma semana, "As demandas sociais do Complexo do alemão".

A justificativa dada pelo General para o pedido, além da desconfiança em relação aos outros atores, foi a vontade de seu comando em se "envolver mais profundamente nas dificuldades e necessidades dos moradores dos dois complexos e a oportunidade ímpar que a instituição tinha de participar num processo humanitário importante dentro do território nacional". Sua experiência no Haiti, ainda como Coronel, segundo ele, fora determinante para sensibilizar seu olhar para estas populações "carentes".

O primeiro grande risco do trabalho de campo foi, então, aceitar ou simpatizar sem reservas com o discurso do ocupante, discurso do estado, por ver nele elementos de possível boa vontade. A evidente diminuição da violência e dos confrontos armados durante este período poderiam também sinalizar para um retrato positivo que

\footnotetext{
${ }^{9}$ Neste período ainda estava concluindo a graduação em Ciências Sociais. Entraria no PPGCS/UFRRJ dois meses depois, com o embrião do projeto de pesquisa que se tornaria, futuramente, esta dissertação. ${ }^{10}$ Não se pode perder de vista a questão abordada por Valladares $(2005$, p. 55) sobre o conhecimento como instrumento para melhor administração e controle da favela e seus habitantes.
} 
amenizasse situações problemáticas e relações arbitrárias que se estabeleceram durante a ocupação.

Antonius C. G. M. Robben (1995), em trabalho de campo entre militares argentinos, aponta que a reconstrução histórica da ditadura militar argentina foi lembrada, contestada, negociada e reconstruída em público pelos seus protagonistas. Foi entrevistando militares que ele se deu conta da importância da sedução ${ }^{11}$ como dimensão do trabalho de campo. Para o autor, esta dimensão é proeminente nas pesquisas sobre conflitos políticos violentos porque os interlocutores possuem especial interesse em fazer o etnógrafo corroborar de suas visões e adotar suas interpretações sobre o campo. Desta forma, conduzir uma pesquisa etnográfica em locais sob conflito violento pode produzir significativos insights sobre as construções e representações que as pessoas fazem deste conflito.

Robben me chamou a atenção para um "afinamento" do texto etnográfico a partir da percepção de que quando o etnógrafo pensa estar vendo o mundo a partir dos olhos de seus interlocutores pode adotar uma percepção ingênua e superficial que ignora que estes interlocutores também estão atentos para o tipo de construção que apresentarão e também imaginam de que forma o etnógrafo enxerga o mundo. Este "afinamento" envolve aquilo que o autor chama de uma "opaca negociação intersubjetiva da compreensão cultural". O risco da sedução etnográfica seria comercializar nossa postura crítica como observadores por uma ilusão de harmonia com os atores do campo. Desta forma não mais buscaríamos a compreensão do ponto de vista dos nativos, mas acreditaríamos termos nos tornado nós mesmos nativos (1995, p. 85). Nesse estágio, sentiríamos ter encontrado alguma verdade ou compreensão profunda sobre o campo. Somente quando se olha para trás, criticamente, é que se percebe o quanto houve inibição pessoal em provocar questões críticas nos/ e com nossos interlocutores. Percebe-se, então, que se confundiu sedução com empatia (1995, p.86).

Corri este risco não somente durante o trabalho de campo entre militares, mas

\footnotetext{
${ }^{11}$ Sedução,para Robben, é usado no sentido de "ser desviado a partir de uma intenção premeditada" (p. 83). Ele prefere o termo a outros, como encobrimento, manipulação ou engano, que carregam forte sentido de desonestidade e más intenções. A sedução pode ser intencional ou inconsciente, podendo ser comparada às formas com que cineastas, diretores de peças teatrais, artistas ou escritores procedem para absorver totalmente a atenção de sua audiência (p. 83).
} 
também entre policiais, integrantes de ONG's, líderes comunitários e/ou religiosos e outros moradores do Complexo do Alemão. Quanto aos militares, reconheço que a simpatia da recepção inicial somada a possibilidade de, ainda como estudante, participar ativamente de um importante processo de ação do estado em uma região simbolicamente importante da cidade do Rio de Janeiro foi um grande risco de perder o foco e a fineza do olhar ao qual me propunha. $\mathrm{O}$ afastamento das instâncias de poder após a troca de comando na Força de Pacificação foi um importante ponto de inflexão na pesquisa, especialmente pela forma como ocorreu. Embora tivesse sido apresentado ao novo general, o novo comando não compactuava com as mesmas ênfases do anterior, o que levou o projeto de volta a um estágio embrionário. Meu nome foi excluído da lista de e-mails. Penso que o teor do documento sobre as demandas sociais, especialmente quanto ao pedido de anistia aos presos por desacato provocou algum desagrado entre os militares e meu afastamento do papel de mediador.

Quanto à atuação na produção dos documentos, isto não envolveu nenhum tipo de envolvimento financeiro ou apoio institucional para qualquer projeto pessoal. Resolvi aceitar o convite para atuar como pesquisador freelancer. Na gênese do documento sobre as demandas sociais, vi-me profundamente inadequado para a realização de tal tarefa. Afinal, embora tenha tido experiência no passado com assistência religiosa e social em favela, nunca fui morador da região. O que me tornaria mais legítimo e autorizado para falar das demandas sociais daquela região do que os moradores, os líderes religiosos e/ou comunitários e as dúzias de ONG's que desenvolviam trabalhos importantes no território? A resposta, por mais estranha que pareça é esta: o pedido do General. Desta forma, um agente do estado legitimava meu inadequado papel de colaborador exatamente por ser um elemento externo e "não envolvido" com os processos locais. Assim, na sua visão um ator local não seria o agente apropriado para identificar as necessidades da região. ${ }^{12}$ Até que ponto minha

\footnotetext{
${ }^{12}$ Uma das principais reclamações de algumas lideranças locais é exatamente o fato de que o conhecimento local não é levado em conta nas intervenções do estado no território. "Eles acham que sabem o que nós precisamos". Talvez, a questão seja que tais agentes do estado, sejam aqueles da segurança pública ou de outros serviços, entendam que os agentes locais não saibam o que realmente precisam. Esta característica, no entanto, não pode ser considerada exclusivamente para as formas como o estado lida com a favela. Historicamente, o estado brasileiro, especialmente na forma dos governos estaduais e prefeituras, e mais especificamente no Rio de Janeiro, jamais foi muito propenso à escuta atenta das populações locais no planejamento de suas intervenções ou prestações de serviços. Durante a escrita desta dissertação, diversos protestos contra estes governos foram realizados nas ruas da cidade e uma das muitas reclamações foi a forma arbitrária das obras, financiamentos e licitações realizadas em preparativos para os grandes eventos esportivos programados para 2014 e 2016, copa do mundo de futebol e olimpíadas, respectivamente.
} 
aceitação deste papel, por sua vez, não legitimou esse segregacionismo é o limite ético que me proponho a problematizar.

Em 2011, o antropólogo David H. Price publicou obra chamada "Weaponizing Anthropology", onde questionava eticamente o uso das ciências sociais, especialmente a antropologia, em programas do governo americano conduzidos por militares. Para ele, se a I Guerra Mundial foi a guerra dos químicos e a II Guerra Mundial dos físicos, as guerras atuais -em seus aspectos de conhecimento cultural necessário para ocupação e contrainsurgência- são visualizadas por estrategistas do Pentágono como a guerra dos antropólogos (p. 2).

Segundo este autor, os militares estariam utilizando a antropologia como um produto, sem compreender os aspectos transformadores da disciplina quando exercida de forma ética. Os processos de uso da antropologia a fim de subverter movimentos políticos seria muito não-antropológico (p. 3). Assim, recebem algo menos que antropologia. Uma das duas coisas acontece quando a antropologia é militarizada: ou os antropólogos da contrainsurgência se dissociam psicologicamente daqueles a quem estudam, dizendo-se "protetores" deles; ou o processo de identificação etnográfica os levaria a redirecionar suas lealdades dos mestres militares para aqueles a quem estudam (p. 4).

Embora minha aproximação como pesquisador tenha sido justificada pelos militares como algo do tipo "queremos fazer o bem, mas não sabemos como", tenho consciência de que, historicamente, os processos de assistência social são uma das principais formas, ensinadas nos manuais militares, de evitamento de insurgências e mais completo controle de populações pobres durante ocupações e intervenções militares. Não pretendo com isso demonizar os militares que ocupavam aquele território. Ao estabelecer relações pessoais, vi que muitos se sentiam verdadeiramente orgulhosos da diminuição da violência armada local e imaginavam a si mesmos como "libertadores" daquela população ${ }^{13}$. Numa ocasião em que um confronto armado com traficantes ocasionou uma vítima, menor de idade, percebi, na base da força de pacificação, verdadeira comoção e tristeza da parte de alguns. Tento evitar, assim, a desumanização daqueles a quem estudei e o equívoco de vê-los somente como pequenas células institucionais. Entretanto, o fato de acreditarem estar fazendo um trabalho humanitário traz suas próprias sombras.

\footnotetext{
${ }^{13}$ Por todo o tempo, vi sendo utilizada, por militares, a representação de que a população do Complexo do Alemão era "oprimida e dominada" por narcotraficantes armados.
} 
Após esta conversa com o general, que gerou o pedido da produção de conhecimento, fui abordado por um major, responsável pelas operações psicológicas. Esta conversa durou ainda mais que a que tive com o general. O oficial me descreveu pormenorizadamente seu trabalho e propôs que eu participasse, de alguma forma, do treinamento daqueles soldados que estariam em contato com as populações locais. Ele me via como um grande "aliado" daquele processo de "pacificação" e acreditava que o conhecimento mais profundo da cultura local ajudaria no trato e na integração dos militares com as pessoas, evitando muitos conflitos. Como observou De l'Estoile (2002):

\begin{abstract}
"Mais geralmente, a administração dos territórios conquistados implica um trabalho de racionalização, entendida como um esforço de ordenação do mundo colonizado. Os discursos eruditos da antropologia, nas suas várias versões, fornecem instrumentos a esse esforço ao propor critérios para identificação das populações e oferecer quadros de interpretação que permitem conferir alguma inteligibilidade a comportamentos percebidos como desconcertantes. Essa aspiração é frequentemente reivindicada; de fato, a administração justifica a necessidade de produzir conhecimentos sobre as regiões $\mathrm{e}$ as populações que pretende controlar, primeiramente, em termos da sua utilidade prática." (p.67)
\end{abstract}

O major me via como aquele que faria este tipo de trabalho, aquele que traria o conhecimento necessário para o sentimento tranquilizador de domínio "justo" e "humanitário" sobre uma realidade complexa e uma população "carente" e pobre. Este conhecimento produzido traria também o direito moral da dominação (De l'Estoile, 2002). O convite, entretanto, não resistiu à mudança de tropa, poucas semanas depois.

Duas questões principais marcaram a produção do documento. A primeira foi o reconhecimento realista de que não se podera esperar que o exército resolvesse questões estruturais minimamente complexas que são fruto de décadas de descaso do poder público com a região. Então, o documento procurou sugerir ações pontuais e possíveis de serem executadas sem grande movimentação de infraestrutura ou verbas extras- que provavelmente não viriam. Segundo, o que considero mais importante, foi a sugestão de um novo tratamento àquela que considero a principal tensão no relacionamento do soldado com o morador: o desacato.

Price (2011) destaca que a guerra foi a força que levou a ética à antropologia, já que esta sempre esteve nas linhas de frente de batalha. Os financiamentos para pesquisas e questões sobre segurança nacional tiveram profunda influência no desenvolvimento da disciplina. Foram os abusos do conhecimento antropológico em 
tempos de guerra que forçaram a disciplina a desenvolver seus códigos de ética profissional (p. 11). Foi especialmente o julgamento de Nuremberg, depois da II Guerra Mundial, que forneceu a antropologia e a todas as ciências humanas e sociais a base para seus modernos códigos de ética (p. 21). Este autor é absolutamente contra qualquer tipo de aproximação entre antropólogos e militares e rejeita o argumento de que os equívocos militares demandariam melhores contribuições de antropólogos, já que a história desta antiga relação aponta para grandes fracassos dos antropólogos em tentar fazer com que burocratas militares abandonem uma construção estereotipada e racializada do mundo e adotem as perspectivas da antropologia (p. 149).

Lucas, Jr. (2009) propõe um interessante contraponto a Price, classificando três tipos de antropologia em relação aos militares. Ele chama de $\mathrm{MA}^{\mathbf{1}}$ o tipo de antropologia dos militares, onde há o estudo antropológico da cultura militar; $\mathrm{MA}^{2} \mathrm{o}$ tipo de antropologia para os militares, onde os antropólogos são integrados a programas de contrainsurgência, como o Human Terrain Systems (HTS) ${ }^{14} ; \mathrm{MA}^{3}$ o tipo de antropologia para os militares em programas educacionais (línguas, cultura, conhecimentos regionais) nas academias militares $(2009, \text { p. } 85)^{15}$. O encontro anual da American Anthropological Association em 2007 discutiu este aspecto e produziu um relatório ${ }^{16}$ cuja preocupação ética não está em ser contra, a priori, à participação de antropólogos em organizações militares, de defesa ou segurança nacional, mas em participações que possam produzir algum dano, mesmo que não intencional ou não consciente, àquelas culturas estudadas, ou que a ausência da apropriada transparência acadêmica impeça de se obter o completo consentimento dos sujeitos humanos pesquisados $^{17}$. No mesmo ano, surgiu na NCA (Netwok of Concerned Anthropologists), que inclui entre outros, David H. Price, documento chamado "Pledge of Non-

\footnotetext{
${ }^{14}$ Programa do exército norte-americano, lançado no outono de 2007, no governo do presidente George W. Bush, que emprega cientistas sociais para oferecer treinamento e produção de conhecimentos sobre populações locais em ocupações militares, futuras ou em andamento.

${ }^{15}$ Se precisasse qualificar meu trabalho a partir desta forma de classificação, diria que estive realizando $\mathrm{M}^{1}$, embora houvesse tentativas, não consistentes, de que a pesquisa se tornasse $\mathrm{M}^{2}$ e até mesmo $\mathrm{M}^{3}$, caso o convite do major tivesse rendido frutos.

16 Este relatório pode ser acessado no seguinte endereço eletrônico: http://www.aaanet.org/pdf/final_report.pdf

${ }^{17}$ Ao me utilizar deste exemplo não penso que a AAA represente a antropologia feita no Brasil, nem que as recomendações da mesma possam ser aplicadas de forma descontextualizada por aqui, apenas vejo que este problema da associação entre antropólogos e instituições militares foi discutido anteriormente e com consistência entre antropólogos de lá. No Brasil, conforme, demonstraram as pesquisas de Castro e Leirner (2009), pareceu haver, historicamente, uma desconfiança dos militares brasileiros com cientistas sociais, o que provocou mais afastamentos que aproximações.
} 
participation in Counterinsurgency" 18 , que, após posicionar-se contra a participação de colegas na "guerra contra o terror", pontuava também seus próprios limites éticos: "We are not all necessarily opposed to other forms of anthropological consulting for the state, or for the military, especially when such cooperation contributes to generally accepted humanitarian objectives."

Penso que, em meu trabalho de campo, alguns limites éticos foram mantidos. Enquanto produzia os textos e estabelecia relações com atores no campo, sejam eles quais fossem, jamais omiti os objetivos da pesquisa e sob quais instituições estava vinculado à época. Esta transparência produziu suas próprias limitações para o campo quando pesquisei a polícia militar a partir de projeto do ISER ${ }^{19}$. Depois de acompanhar operações e patrulhas, além de passar tempo dentro das bases das UPPs, não seria recomendado, por um tempo, e por questões de segurança, circular sozinho pelo território. Enquanto produzia textos que circulariam entre os militares do exército não omiti nem suavizei críticas que considerei pertinentes e propus medidas que não soaram simpáticas $^{20}$, assim como, enquanto produzia relatórios sobre a polícia, para o ISER, jamais me senti pressionado ou constrangido em minhas posições críticas ${ }^{21}$.

\section{Os riscos da pesquisa em seu segundo momento}

Chamo de segundo momento o intervalo de um ano entre a pesquisa com os militares do exército e a pesquisa com os policiais militares da UPP. Durante este período, circulei entre comerciantes, líderes de movimentos sociais, pessoas ligadas à ONGs, outros pesquisadores, religiosos, comerciantes e até traficantes. Passava dias inteiros entre conversas, refeições e observação, aproximando-me mais de alguns moradores. Fui auxiliado especialmente por dois moradores: a presidente de uma importante ONG local; e dois pastores batistas, um deles colega do curso de graduação

\footnotetext{
${ }^{18}$ Este documento pode ser encontrado no seguinte endereço eletrônico: http://blog.theasa.org/?p=54

${ }^{19}$ Instituto de Estudos da Religião.

${ }^{20}$ A proposta da "anistia" causou certo desconforto quando publicamente proposta, em uma das últimas reuniões com lideranças religiosas. Reconheço que a palavra, no Brasil, depois das intensas discussões à época do fim da ditadura e, atualmente, com a polêmica Comissão da Verdade, traz peso e tem grande lastro histórico nas instituições militares, mas decidi mantê-la já que não encontrei outro dispositivo legal que abarcasse aquilo que estava sendo proposto.

${ }^{21}$ Evidentemente, isto não significa que não tenha sido seguida uma "etiqueta" de campo. A exposição não solicitada de posicionamentos críticos às instituições as quais pesquisava poderia ter fechado muitas entradas.
} 
em ciências sociais. Estes, além das conversas, apresentaram-me algumas pessoas que contribuíram decisivamente para esta fase da pesquisa.

Estabeleci a Rua Canitar, no bairro de Inhaúma, e o chamado Morro da Fazendinha, como base de apoio. A escolha se deu por dois motivos. Primeiro, pelos contatos que construí no local- o que é importante em termos de segurança pessoal. Segundo, por se tratar de uma via de fundamental importância simbólica, já que foi por muitos anos quartel-general do Comando Vermelho, não só no Alemão, mas em todo o Estado do Rio de Janeiro. "Tomar" a Rua Canitar sempre foi visto como estratégico, tanto nas guerras entre facções, quanto no combate ao narcotráfico. Os violentos confrontos ocorridos lá ainda estão vivos na memória daqueles que conheci.

Escutei estórias de violência, tortura, abuso e crime ${ }^{22}$. Tive acesso a testemunhas de eventos e importantes processos que se deram na região. Além da história oficial, escutei os outros lados das narrativas de ocupação e violência. Tive tantos contrapontos e fortes relatos que corri o risco de perder a multivocalidade e a polifonia a qual me propunha para dar voz, somente, a estes muitos atores que tanto tinham para falar. Neste período, corri também o risco de construir uma imagem tão demoníaca da polícia que seria impossível estar entre eles na próxima fase da pesquisa. Corri o risco de simpatizar tanto com aquelas narrativas, deixar-me seduzir a tal ponto, que perderia a capacidade de olhar com meus próprios olhos.

Fora isso, os acessos que consegui; as portas que se abriram e as que se fecharam, a circulação multisituada que obtive, os distintos locais por onde estive, contribuíram, cada um a sua maneira, para que esta dissertação fosse produzida.

\section{Os riscos da pesquisa entre policiais}

Minha entrada para o trabalho de campo com as UPPs do Complexo do Alemão se deu através de projeto encabeçado pelo ISER que visava a construção de projeto pedagógico para o treinamento dos policiais das UPPs. Minha chegada foi precedida por ofício e comunicado aos comandantes das unidades para que o trabalho fosse facilitado.

\footnotetext{
${ }^{22}$ Não afirmo com isso que a história da Fazendinha se resuma a uma história da violência local, mas procurei direcionar meu olhar para as narrativas de encontro das populações locais com o estado, através de seus agentes. Nesse encontro, a violência encontra protagonismo. Além disso, o tráfico de drogas continuou a exercer poder no território, tanto simbólico quanto armado. Ao final da pesquisa, este poder pareceu aumentar consideravelmente e os confrontos e a tensão no local cresceram proporcionalmente.
} 
Logo, a primeira pessoa que procurei e conversei, nas unidades que pesquisei, sempre foi o comandante da unidade. Meu trabalho consistia em produção de um relatório sobre o funcionamento da unidade ${ }^{23}$. Este relatório seria base para a construção de um novo projeto de treinamento para estes policiais.

O primeiro risco corrido foi me deixar seduzir pelo primeiro e, geralmente, cordial contato inicial com os comandantes. Eles apresentavam, primeiramente, a visão de cima do funcionamento da unidade e suas múltiplas relações com os atores internos e externos à polícia. Aquilo que me mostravam era, em parte, a construção de uma imagem que eram obrigados a expor a todo momento, devido a forte publicidade tanto do projeto quanto da região em que atuavam e, em parte, aquilo que esperavam que eu deveria ou gostaria de escutar. Tive que estar atento a suas reduções, omissões e simplificações. Por outro lado, a postura que adotei e o objetivo do projeto parecia lhes provocar simpatia. Se meu objetivo era não somente fazer o retrato mas também apontar as dificuldades e o que parecia não funcionar no modelo, estes comandantes sempre tinham importantes contribuições e críticas ao modelo vigente, muitas feitas com o pedido de não serem incluídas no relatório.

O segundo risco foi não conseguir conquistar a confiança dos soldados e

\footnotetext{
${ }^{23}$ Deveria seguir o seguinte roteiro de observação, que foi elaborado pela equipe coordenadora do projeto: 1. Descrição Geral da Base (cômodos, infraestrutura, espaço de atendimento ao público). Observar também a origem do local, caso não seja container. Verificar se costumava ter outro uso antes da "pacificação" (sede do GPAE, base do tráfico/milícia, etc); 2. Verificar se existem espaços para aulas e/outras atividades com o público externo (Registrar, por exemplo, quais cursos são dados e por quais professores. Além disso, é fundamental ter informações sobre o público-alvo); 3. Observar a presença do comando (oficial e sub) na base (É importante observar se eles têm contato com os demais policiais); 4. Quantificar, aproximadamente, o número de soldados presentes na base em cada dia de observação (vale a pena observar a distribuição das policiais femininas); 5. Observar a distribuição destes nas diferentes funções, descrever tais funções e enumerar os policiais em cada uma destas (É importante estar atento aos contatos que os policiais de cada setor fazem com os moradores. Há visitas às instituições locais? Como elas acontecem?); 6. Observar a distribuição dos soldados pelas favelas (Em que partes da favela eles estão? Quando estão parados, estão sozinhos ou em grupos?); 7. Observar se eles se deslocam com frequência no cotidiano; 8. Observar se eles andam sozinhos ou em grupo; 9. Observar se há deslocamento de viatura e se o porte do fuzil é visível. Em que casos se dá esse deslocamento? A viatura é usada em casos de emergência?; 10. Onde os policiais almoçam? Eles saem com frequência da favela onde atuam?; 11. É importante observar como se dá a interação entre policiais, comerciantes locais, religiosos e moradores em geral; 12. Em relação às abordagens, é importante observar como elas se dão. Com quem? São frequentes? Qual é a postura do policial?; 13. Descrever ocorrências que observamos na base e fora delas. (Em que consistem tais ocorrências? Como foi o diálogo, caso tenha havido? Qual foi o encaminhamento dado? Quais comentários essas ocorrências suscitaram entre os policiais?); 14.Observar a interação entre os diferentes níveis hierárquicos (principalmente entre os praças) no desenvolvimento das atividades de rotina e durante as ocorrências (como se distribuem tarefas no atendimento das ocorrências? Quais são os policiais destacados para cada tipo de ocorrência? Há ocorrências nas quais o comandante ou o sub são acionados? A supervisão é acionada no atendimento de ocorrências?)
} 
graduados, cuja observação da performance mais me interessava. No início, houve desconfiança, mas a ideia de contribuir com um projeto que tentaria melhorar seu treinamento ${ }^{24}$ e suas condições de trabalho parecia motivá-los. Logo depois de um curto período de gelo inicial, contavam suas experiências, seus medos, suas motivações para estar na instituição.

O terceiro risco foi, após o ano do trabalho de campo onde vi serem construídas as piores representações possíveis de policiais militares, me aproximar destes atores munido de preconceitos e de uma imagem que sobrepusesse o peso da farda, do fuzil e da instituição aos seres humanos que lá estavam. Assim, fez-se necessário evitar generalizações como os policias são assim ou os policiais agem desta forma para que me rendesse à complexidade e as nuances que este campo apresentava. Escutar suas queixas e estórias, passar tempo com eles/elas, vê-los(as) trabalhar foi fundamental para que houvesse o processo de simpatia etnográfica e o campo se tornasse possível.

\section{Riscos à integridade física do pesquisador}

Por fim, o quarto risco foi o da integridade física do pesquisador.

Durante a pesquisa com o exército consegui acesso para participar das incursões militares ao território e observar as operações. Passei um tempo considerável dentro do departamento jurídico da Força de Pacificação para que o responsável definisse quais termos deveriam constar para serem assinados. No documento que assinei, o exército se eximia de qualquer responsabilidade sobre dano físico sofrido a minha pessoa enquanto eu estivesse acompanhando as operações, inclusive dizia que não seria responsável por qualquer tratamento médico-hospitalar. Decidi, contudo, neste momento da pesquisa, não observar estas operações acompanhado de militares.

No segundo momento, lidei quase sempre com as representações coletivas que veem a favela como local de risco e violência. Jamais me senti ameaçado, mesmo quando minha presença era claramente notada como a presença de um "estrangeiro". Fui, algumas vezes, advertido pelo fato de que meu porte físico e aparência "pareciam de polícia”. Percebi que há uma construção imaginária sobre a figura do policial P2, que seria um agente ligado à inteligência e que andava à paisana por locais de investigação.

\footnotetext{
${ }^{24}$ Reclamar do treinamento, por considerá-lo insuficiente e inadequado, foi unanimidade entre aqueles com quem conversei.
} 
Não foram poucas as ocasiões em que disseram que eu poderia ser associado a esta figura.

Enquanto estive pesquisando as unidades de polícia pacificadora, contudo, o risco efetivamente se configurou. Lembro-me de um conselho dado pela Professora Miriam Santos sobre o cuidado para não perder o "medo", já que os riscos se tornariam realmente perigosos quando o etnógrafo deixasse de tomar certos cuidados. Olhando para trás, posso reconhecer que corri alguns riscos e me expus, talvez sem necessidade. Durante esta fase da pesquisa, passei considerável tempo dentro das unidades de polícia pacificadora e no acompanhamento de operações policiais, além de ter circulado sozinho pelo território.

Em duas das unidades pesquisadas, Alemão e Nova Brasília, policiais haviam sido mortos em serviço ${ }^{25}$. A relação entre os policiais e os moradores ia da calculada indiferença à hostilidade. Muitas destas rondas e operações terminavam em tiros, perseguições ou tumultos. Não estive no fogo cruzado ou tumulto, mas presenciei algumas perseguições ou "correrias" conforme descrevo no capitulo especifico. No momento da pesquisa, o clima era muito tenso e a possibilidade de confronto, especialmente na área coberta pela UPP Alemão, era real.

Mesmo depois de acompanhar, como observador, operações policiais, circulei sozinho pela favela, fiz refeições, cheguei e voltei de teleférico e a pé, estive numa sexta-feira à noite na Praça do Conhecimento, visitei o comércio local. Fui advertido do risco, mas efetivamente não me senti ameaçado. Posso ter me enganado. Posso ter posto em risco minha vida. Penso, ainda hoje, até que ponto o medo ou sua ausência são determinantes para construção de uma etnografia em locais de conflito violento. Nesta etnografia, acredito ter trabalhado com cautela e discrição, mas o medo realmente só surgiu depois que o texto estava sendo construído e aqueles que o liam se surpreendiam com os riscos que enfrentei.

Jeffrey A. Sluka (1995) realizou trabalho de campo em Belfast, com entrevistas e observação participante, tendo estudado as dinâmicas sociais do apoio popular ao Irish Republican Army (IRA) e Irish National Liberation Army (INLA). Em artigo sobre como lidar com o perigo no trabalho de campo aconselha a não ser complacente sobre os perigos que encara e a não tratar a situação como um jogo ou como uma aventura. Segundo ele, não se deve ignorar potenciais ameaças quando surgem já que elas

\footnotetext{
${ }^{25} \mathrm{Em} 2014$, outros policiais foram mortos na região.
} 
raramente se vão se a ignorarmos. Quanto aos rumores de perigo, sejam verdadeiros ou falsos, precisar ser tratados. Se forem falsos, devem ser publicamente negados em vez de ignorados. Se verdadeiros, deve-se trabalhar para convencer as pessoas que o etnógrafo não é uma ameaça, e se a ameaça for direta, o melhor a fazer é ir embora. Conclui que é melhor ser paranoico sobre estas questões do que complacente.

Poucos meses depois do termino do trabalho de campo sonhei que estava no Complexo e três adolescentes armados passavam por mim. Um deles se voltava e me reconhecia como policial. Apontava a arma. Dizia: "perdeu”. Consigo fugir. Corro. O sonho acaba. Não sei se estava tomando consciência do risco naquele momento do sonho ou se a sublimação do meu medo irrompia através do inconsciente.

No mês anterior, numa última conversa com um importante ator do campo, ele contou que, durante o período em que eu estava circulando com policiais, dois jovens traficantes armados foram a uma igreja perguntar por ele, pois souberam que tinha alguém "a paisana" andando com policiais no Complexo. "Nunca andei com policiais", ele disse. Não sei se algum dia saberei se, na verdade, era a mim que procuravam.

Esta questão me faz refletir até que ponto esta lógica do medo não é mais uma reprodução das representações sociais associadas àquele território como local de perigo, ameaça e violência. Será que minha gestão interior do medo foi feita de forma complacente, usando os termos de Sluka, ou apenas resisti a construir minha própria imagem daquele lugar como decisiva e estruturalmente marcado pela violência e medo?

Por fim, proponho uma outra forma de abordagem metodológica no olhar etnográfico sobre o encontro entre os agentes do estado e as populações locais. Abandono a sedução da ideia de construir a polícia como uma entidade externa, e quase sempre antagônica, à favela. Admitindo a proposta das Unidades de Polícia Pacificadora como uma ocupação policial permanente, sem previsão de término (Rodrigues e Siqueira, 2012), de forma que, por vezes, como observado por Rodrigues e Siqueira (2012) no morro da Providência, até o nome da favela é confundido com a UPP; admitindo, também, que, independente da eficácia do modelo, a ocupação policial permanente representa um evento marcante na história e no cotidiano das favelas ocupadas; e que a presença policial e as mudanças na sociabilidade e na regulação do cotidiano se tornam indispensáveis para a compreensão das dinâmicas sociais locais, considero a polícia, após a ocupação das UPPs elemento constitutivo e promotor de uma nova dinâmica social na favela. A polícia, na proposta de ocupação permanente, passa a 
fazer parte da favela, tornando-se mais um dos diferentes grupos que integram de diferentes formas o mesmo espaço social. Estes grupos, contudo, possuem diferentes hierarquias na ação social. A polícia, nas favelas do Complexo do Alemão, não ocupa o mesmo espaço hierárquico que ocupa, por exemplo, nos bairros vizinhos de Ramos e Vila da Penha. Na favela, a polícia parece pretender ocupar um superespaço de regulação.

\section{Mais um pouco de reflexividade}

Pensei, quando entrei no campo, que estudaria religião na favela e que este seria meu tema caro, mas ainda não estava satisfeito. Defini relativamente cedo que estudar religião "para dentro" não me interessava, mas somente em suas múltiplas relações com o espaço público. Quando o Complexo do Alemão surgiu em minha trajetória, com todos aqueles processos "espetaculares" envolvendo o exército e a polícia, imaginei ter encontrado a cereja do bolo. Mas algo me faltava. A pesquisa estava em andamento e às vezes sentia que faltava aparecer o coelho branco para ser perseguido ou uma briga de galos. Quando pesquisei a polícia, na última fase do trabalho de campo, e descobri decepcionadamente que não estava interessado em ser mais um dos colegas que discutem favela ou segurança pública em si mesmas, vi que o que me interessava realmente estava o tempo todo aparecendo nos textos e nos apontamentos sem que me desse conta. O que me fascinava não era como a religião se aproximava do Estado, mas como o Estado articulava e se relacionava com diferentes instituições para gerir alguns territórios. Fascinava-me descobrir a grande ficção do "Estado" e da "Religião", vê-los perder suas letras maiúsculas para se transformarem no "estado" e na "religião" concretos, que só existem na ação social de seus agentes humanos, em seus microprocessos e microinterações, contrastadas com a apresentação teatral e espetacular de seus grandes eventos. A partir desse processo, quero olhar a favela, a segurança pública, a religião no espaço público, o estado e sua violência como temáticas que sempre me interessaram.

As escolhas e não escolhas, as entradas, as recusas, as interações, os locais que frequentei e os que não quis estar são frutos do acaso, da coincidência e das escolhas conscientes, pouco conscientes e inconscientes do etnógrafo. Para iluminar este processo, desvelarei nos próximos parágrafos elementos que podem ter sido 
determinantes para a configuração desta etnografia.

A experiência mais remota que tenho da favela se dá numa infância distante. Morava no bairro de Bangu, zona oeste da cidade do Rio de Janeiro, num condomínio de classe média baixa. Meus pais ainda eram casados. Naquele fim-de-semana, íamos ao Barra Shopping fazer compras. Deveria ter uns quatro ou cinco anos de idade. Não possuíamos carro e a viagem de ônibus parecia durar uma eternidade. Passávamos pela Cidade de Deus quando o ônibus foi assaltado. Acho que alguém puxou uma pulseirinha dourada que eu usava. Tive muito medo. Meu pai pareceu me segurar contra seu corpo e o ladrão me olhou nos olhos. Provavelmente, nada disto aconteceu como a memória evoca, mas esta é a construção que permaneceu. Lembro-me de ter escutado a palavra "favela" e minha associação imediata foi a de local perigoso onde pessoas más fazem coisas ruins a pessoas boas, como eu ainda achava que era. A Cidade de Deus era favela, era perigosa e tinha aquelas pessoas que me assustaram. $\mathrm{O}$ homem que levou ou não levou minha pulseirinha era negro e acho que usava boné e bermuda. Fiquei com medo de pessoas negras e me lembro de ter refletido quando vi que a doméstica que cuidava de mim era negra e eu gostava dela. Meus primos maternos também, assim como minha irmã de criação. Concluí que roubar pulseirinhas de crianças não era coisa de pessoas de pele escura, mas de pessoas de pele escura que não eram boas. Pessoas de pele clara também poderiam ser más. E na favela havia pessoas más que roubavam pulseirinhas de crianças $^{26}$.

Ainda nesta casa de Bangu, num segundo período da vida, entre os dez e os treze anos, a favela ganhava conotações mais ricas na construção que fazia dela. No auge de uma febre por fliperamas, via os domingos como os piores dias da semana, já que era raro encontrar locais abertos para o jogo. Só na favela próxima, chamada de 77. Então, os "filhinhos da mamãe" de classe média baixa iam para a favela jogar fliperama. Lá andávamos e falávamos imitando os trejeitos dos "nativos" mais legais e que também jogavam. Um deles, não tão popular, era o Diogo, negro, magrelo, de uns 12 anos de idade, pouco mais alto que eu, que só vivia sem camisa e de bermuda. Tinha fama de não ser muito "certo da cabeça", meio "zureta", mas "não rasgava dinheiro" e já havia capinado o quintal da casa de quase todo a vizinhança. Numa disputa do jogo Street Fighter, investiu seu dinheiro em fichas e as perdeu numa partida contra mim. Na

\footnotetext{
${ }^{26}$ Não sei bem porque, pouco tempo depois, deixei cair do ônibus um boneco do Batman que havia acabado de ganhar. Minha mãe riu e eu fiquei com muita raiva imaginando que crianças más da favela estariam agora com o Batman que caiu do ônibus.
} 
última partida, ameaçou-me. Perdeu de novo e fomos para o lado de fora brigar. Acho que as vitórias no jogo virtual me animaram e camuflaram o medo que tinha de brigas. Estimulado pelas ameaças, brigamos, e o saldo final dado pelos juízes foi que eu bati e Diogo apanhou. Isso era uma raridade, porque normalmente eu apanhava e já estava me acostumando com isso. Por uns três dias ganhei o respeito de todos, até apanhar de outro e voltar à estaca zero de prestígio.

Todos os dias via o Diogo passar na rua e me animava a ideia de ser "mais forte" que alguém. Pouco tempo depois, contaram-me que os tiros que havíamos escutado na noite anterior o haviam matado. Não me lembro se foram traficantes ou policiais, mas mataram o menino magrelo com muitos tiros e o corpo ficou quase o dia todo coberto com um lençol branco numa pequena praça a cem metros da minha casa. Não sei se realmente vi seu cadáver ou se o imaginei depois de escutar aquela descrição, mas pela primeira vez vi que meninos da minha idade poderiam morrer. Poderíamos brigar com o Diogo e até bater nele, mas, no meu pensamento infantil, atirar numa criança e matá-la não poderia fazer parte deste mundo. Nunca mais esqueci o que aconteceu.

No lugar onde ficou exposto o corpo do menino crescia uma pequena favela, que parecia ameaçar a "tranquilidade" da burguesia empobrecida de Bangu. Escutava comentários de que ela "havia crescido rápido demais" e que "não deveríamos ir lá, pois era perigoso”. Em 2013, assisti ao filme “O Som ao Redor”, de Kleber Mendonça Filho. Numa de suas cenas mais interessantes, uma menina sonhava que sua casa num bairro de classe média de Recife era invadida por "favelados". Tive este sonho várias vezes durante este período da vida.

Num ano novo, quando já tinha 20 anos de idade, em meu último ano naquela casa, um dos cachorros da família fugiu. Um poodle velho e mal-humorado. O portão da casa estava entreaberto. Alguém contou que viu o velho Lupi com sua roupa esgarçada cinza andando pela favela. Lembro-me de ter ouvido um vizinho concluir que alguém da favela havia roubado o cachorro. Acho que outra pessoa também sugeriu que o traficante local não gostava que roubassem nada nas proximidades e que eu deveria procurá-lo. Ainda com a cabeça fervilhando, um morador daquela favelinha vizinha apareceu com aquele cachorro rabugento no colo e disse que o encontrou na rua, e havia cuidado dele, pois ele estava muito assustado com os fogos e com fome. Agradeci efusivamente. Ofereci uns trocados, que foram educadamente recusados. 
Um ano depois, no final de 2002, morava no bairro do Méier, periferia carioca, e era estudante de teologia numa universidade protestante. Vinculado à Igreja Presbiteriana do Brasil acabei aceitando "pastorear" uma pequena igreja na favela de Camarista Méier ${ }^{27}$, uma congregação de uma igreja próxima. Escutei que era uma igrejinha pobre e sofrida, que havia passado por alguns traumas recentes e andava desarticulada e esvaziada. Assumiria o trabalho no primeiro domingo após o natal. Peguei o endereço num boletim da igreja mãe e, ainda no sábado, resolvi ir ao local para reconhecer o ambiente. Fui a pé. Subi a favela e encontrei o local após árdua caminhada. Ainda não sabia que permaneceria lá por sete anos.

No dia seguinte, coloquei o terno e fui para lá, aos vinte e um anos de idade, e cheio de certezas. Falei por uma hora coisas bonitas que havia aprendido nos livros de teologia. Havia dez pessoas inicialmente. Quando acabou o culto dominical, elas me cercaram, conversaram comigo, fizeram-me lanchar e trataram-me com um carinho que nunca havia experimentado na instituição religiosa. Fui lá para cuidar deles e ensiná-los as verdades que aprendia, mas eles é que cuidaram de mim e me ensinaram muitas coisas sobre a vida. A primeira delas é que eu não era tão bom quanto pensava.

Fui pastor daquela igrejinha na favela por sete anos. Lá passei por todos os processos internos e ritos necessários para a ordenação de ministro religioso presbiteriano. Envolvi-me num projeto social com crianças e a congregação começou a atrair algumas pessoas simpáticas ao projeto mais "liberal" do seu pastor. Recebíamos homossexuais, casais não casados, saíamos para beber e dançar forró, para horror de instituição extremamente conservadora como é a Igreja Presbiteriana do Brasil. Ganhei fama de liberal, desviado, marxista, perigoso e várias outras coisas. Por sete anos, estive numa favela e conheci seus moradores, suas dinâmicas, suas histórias, tristezas e alegrias. Esta foi uma experiência determinante para minha formação como ser humano e antropólogo.

Em meu último ano como pastor, já estudante de ciências sociais, estive como pastor auxiliar de uma igreja grande e rica no bairro de Copacabana, zona sul da cidade. Esta experiência é marcante por outros motivos. Aos 28 anos de idade, integrava, com a possibilidade de presidir caso fosse necessário, o Conselho gestor desta instituição ${ }^{28}$. Era o mais jovem e o de menor ascendência socioeconômica. Era comum que, nesta

\footnotetext{
${ }^{27}$ No bairro do Engenho de Dentro.

${ }^{28}$ A Igreja Presbiteriana do Brasil é gerida por um conselho masculino de pastores e presbíteros, estes eleitos por uma assembleia onde os membros da igreja votam. Todos, neste conselho, têm direito a voto e, pelo menos na teoria, igual representatividade.
} 
instituição religiosa, generais, políticos, artistas, juristas, desembargadores, me vissem como autoridade institucional máxima e me tratassem com algum tipo de reverência e formalidade, mesmo que por vezes a diferença de idade chegasse a mais de cinquenta anos ${ }^{29}$. Durante o curso de teologia, éramos ensinados a estar sempre prontos a, se preciso, enfrentar estas pessoas e a rivalidade entre pastores e presbíteros era uma marca desta instituição.

Outro fator interessante é que por dois anos, ainda funcionário de uma grande instituição financeira, trabalhei em área que cuidava dos investimentos dos clientes milionários, o que me possibilitou contatos diários com pessoas de uma elite a qual eu não pertencia.

Estas experiências talharam-me a habilidade social de circular e lidar com pessoas de maior ascendência política, econômica e social que a minha, de uma elite a qual, de fato, nunca fiz parte. Esta habilidade, que se desenvolveu de forma inconsciente por um período, envolve certa desenvoltura, aparência, postura corporal e forma de me comunicar que, possivelmente, transmite sinais verbais e não verbais que, culturalmente, são identificados como se eu fosse alguém “confiável”, que "pertenço a este lugar" ou "posso assumir determinadas funções ${ }^{30}$ ou obter determinadas informações".

Goffman (2007) já havia demonstrado que quando um indivíduo chega à presença de outros, estes procuram obter informações a seu respeito: "A informação a respeito do indivíduo serve para definir a situação, tornando os outros capazes de conhecer antecipadamente o que ele esperará deles e o que dele podem esperar" (p. 11). A aparência e a conduta são importantes fontes de informação quando se trata de desconhecidos, para que se possam aplicar estereótipos não comprovados que apontem, mesmo que por repetição, qual tipo de indivíduo é provavelmente encontrado em dado cenário social.

Jamais procurei transmitir intencionalmente qualquer tipo de informação falsa a meu respeito. Assim, procuro me isentar da acusação de fraude ou de dissimulação,

\footnotetext{
${ }^{29}$ Preferia, entretanto, estar entre os mais simples. A artificialidade e o rigor destas relações me incomodavam de forma que sempre tentava "quebrar o gelo" e torná-las mais informais e leves. Poucas vezes tive sucesso.

${ }^{30}$ Enquanto escrevia a dissertação assumi, por um semestre, a coordenação geral de um campus universitário. Não possuía, ainda, a formação acadêmica que penso necessária para tal função, nem vasta experiência em gestão, mas, depois de poucas semanas como docente, recebi o convite para a função, a qual desempenhei por um semestre letivo. Considero este mais um exemplo da argumentação anterior.
} 
contudo reconheço que quando chegamos à presença de outras pessoas existe alguma razão que nos leva a atuar de forma a transmitir a elas a impressão que nos interessa transmitir (Goffman, p. 13), especialmente nas primeiras impressões.

Utilizo-me mais uma vez da notável contribuição deste autor e, desde já, aponto a utilização, através de toda esta etnografia, da ideia de representação como "toda atividade de um indivíduo que se passa num período caracterizado por sua presença contínua diante de um grupo particular de observadores e que tem sobre estes alguma influência" (Goffman, p. 29) e de fachada como "o equipamento expressivo de tipo padronizado intencional ou inconscientemente empregado pelo indivíduo durante sua representação" (Goffman, p. 29). O mundo é uma reunião, e a própria vida uma encenação dramática, onde, na presença de outros, o indivíduo manifesta sinais confirmatórios que apontam para aquilo que ele precisa transmitir, ressaltando os valores oficialmente reconhecidos pelo grupo.

Em etnografia sobre assaltantes de banco, Jania Perla de Aquino (2010) destaca o quanto seus interlocutores estavam cientes da dimensão expressiva do comportamento, de tal forma que suas aptidões cênicas aguçaram sua sensibilidade para o aspecto da performance na relação destes com a etnógrafa. Ela reconhece que, conscientemente, produziu uma "imagem de si" que facilitaria a entrada e o desenvolvimento do campo. Esta entrada envolvia aspectos físicos e até mesmo de temperamento. Quanto ao primeiro aspecto, ressaltando se tratar de um campo fortemente marcado pela masculinidade e consciente das preferências estéticas de seus informantes, decidiu vestir-se de um modo especificamente "apropriado", evitando roupas que marcassem o corpo, saltos, batons de cores fortes, mantendo o cabelo preso e até usando uma aliança de compromisso. Quanto ao segundo aspecto, conta que, propositadamente, estimulava a "vaidade" que os assaltantes possuem de suas competências e habilidades nos assaltos e mostrava-se sempre calma e interessada em suas vidas. Assim, a autora apontou que cada lado da interação etnógrafo-interlocutor estava mais ou menos consciente de que apresentava um certo tipo de desempenho em campo. "Trata-se de dramatizações que ganham contornos a partir das expectativas das pessoas e coletivos etnografados e por nosso empenho em encontrar vias de acesso a informações, dados e diálogos que consideramos relevantes" (Aquino, 2010, p. 97).

Vi, durante a realização deste trabalho de campo, diferentes "imagens" sobre a minha presença sendo relacionadas, construídas e até desconstruídas. Não me opus 
quando, no início da pesquisa, minha formação anterior em teologia e até o passado como pastor, foram acionados para "quebrar o gelo" entre religiosos locais. Nesta época, já não tinha nenhuma vinculação religiosa, ou qualquer prática de "espiritualidade", e já me encontrava entre aqueles que se dizem "agnósticos", contudo preferi não versar sobre minha trajetória ou opiniões teológicas ou religiosas, e aceitei, silencioso, quando me identificavam como fazendo, de alguma forma, parte daquele grupo. Um dos meus principais interlocutores, especialmente, dizia se sentir à vontade em conversar porque eu seria um "homem de deus". A decisão em não falar sobre minha pessoa foi um artifício de discrição e não uma recusa em me apresentar. Aquilo que sempre deixava claro era a intenção da pesquisa e minha vinculação institucional com a universidade.

Não entendo que o teólogo tenha se confundido com o estudante de antropologia quando, em dado momento da pesquisa, etnografei eventos religiosos. Apesar do passado religioso, não me considero "nativo". Contudo, a formação em teologia facilitou, além de algumas entradas, o entendimento de certas representações e estruturas de pensamento acionadas por estes agentes religiosos. Meu olhar para o campo foi, entretanto, disciplinado pelas ciências sociais.

Num segundo momento da pesquisa, obtive entrada entre um grupo religioso protestante que não se envolveu nesta aproximação com o Exército. Lá, desenvolvi laços de amizade com os líderes e obtive importantes impressões e relatos, mesmo consciente de que estes, no fundo, achassem que minha aproximação do grupo poderia ocasionar um "retorno do filho pródigo". Isto, para decepção dos meus interlocutores, não aconteceu.

$\mathrm{Na}$ maior parte da pesquisa, todavia, estive na condição de "antropólogo" e "pesquisador", sem qualquer referência a outro tipo de formação. As vinculações institucionais foram três. No início, enquanto estive a pesquisar a ocupação militar, era "pesquisador", estudante da Universidade Candido Mendes. Num último momento da ocupação do exército e durante os primeiros meses de funcionamento das Unidades de Polícia Pacificadora, como pesquisador ligado à Universidade Federal Rural do Rio de Janeiro. Algumas vezes, minha vinculação de pesquisador associado do Instituto de Estudos da Religião (ISER) foi acionada. Na última fase da pesquisa, enquanto estive pesquisando a ação da polícia, minha entrada foi totalmente institucional, o que será detalhado no respectivo capítulo. 
A questão mais difícil na disciplina deste olhar foi o tipo de sentimento que nutria pelos meus interlocutores e as instituições as quais pertenciam. Militares, policiais, traficantes e religiosos não são o tipo de pessoas que me despertem qualquer tipo de simpatia inicial, tampouco as instituições que representam. Aproximei-me deles como seres humanos ricos e complexos, que são muito mais do que aquilo que a fachada mostra e, durante os dois anos da realização desta pesquisa, desenvolvi laços de amizade e conheci pessoas absolutamente interessantes, em diferentes instituições. Estas pessoas, evidentemente, tinham seu comportamento "afetado" pela presença do pesquisador. Procurei estar consciente deste processo e estive atento àqueles momentos mais informais, menos "institucionais" possíveis. Militares, policiais, assistentes sociais e religiosos são treinados numa precisa exibição de sua fachada e são poucos os momentos em que relaxam desta atuação, especialmente quando descobrem estar sendo pesquisados, por isso precisei de especial sensibilidade para que não se "fechassem" e, de alguma forma, encontrassem "simpatia" naquilo que eu fazia. Para isso, sempre destaquei a importância da pesquisa e do papel de cada interlocutor nela. Enquanto estive entre policiais das Unidades de Polícia Pacificadora, por diversas vezes fui apresentado espontaneamente como alguém que faria um trabalho para melhorar as condições de trabalho do policial na UPP. Aqueles que acreditaram nisto foram os que relataram aquilo que dificilmente contariam para qualquer pessoa. Pretendo, em cada capítulo, detalhar melhor as condições de entrada no campo e suas especificidades.

Penso, com este artigo, ter desnudado subjetividades e tratado a maior parte das problemáticas referentes às minhas entradas e diferentes posições em relação aos interlocutores durante a realização da pesquisa. Lancei, também, um olhar sobre a pessoa do etnógrafo como objeto de análise, tanto quanto suas diferentes posições estabelecidas como interlocutor no campo de pesquisa e seus respectivos riscos.

\section{Referências}

AQUINO, Jania Perla de. Príncipes e castelos de areia: um estudo da performance nos grandes 
roubos. São Paulo, Biblioteca 24x7, 2010.

CASTRO, Celso. Em campo com os militares. In: Celso Castro; Piero Leirner (Orgs.). Antropologia dos militares: reflexões sobre pesquisas de campo. Rio de Janeiro: Editora FGV, 2009.

Ed. 2004. O Espírito Militar: Um Antropólogo na Caserna. Rio de Janeiro: Jorge Zahar

DE l'ESTOILE, B. Ciência do Homem e Dominação Racional. In de l'Estoile, B., Neiburg, F. e Sigaud, L. Antropologia, Impérios e Estados Nacionais. Rio de Janeiro, Relume-Dumara, 2003, pp. 61-93.

GOFFMAN, Erving. A representação do eu na vida cotidiana. Tradução de Maria Célia Santos Raposo, 14a. Ed. Petrópolis, Vozes, 2007.

HARAWAY, Donna. Saberes localizados: a questão da ciência para o feminismo e o privilégio da perspectiva parcial. Tradução de Mariza Corrêa. Cadernos Pagu 5(2), Campinas, 1995.

LUCAS, George R. Anthropologists in arms: the ethics of military anthropology. Altamira Press, United Kingdom, 2009.

PRICE, David H. Weaponizing anthroplogy. California, Counter Punch, 2011.

ROBBEN, Antonius C. G. M. The politics of truth and emotion among victims and perpetrators of violence. In: Carolyn Nordstrom e Antonius C. G. M. Robber (orgs). Fieldwork under fire: contemporary studies of violence and survival. Berkeley, Los Angeles, London, University of California Press, 1995.

RODRIGUES, André \& SIQUEIRA, Raiza. As unidades de polícia pacificadora e a segurança pública no Rio de Janeiro in Unidades de polícia pacificadora: debates e reflexões, organizado por André Rodrigues, Raíza Siqueira e Mauricio Lissovsky, Rio de Janeiro, ISER, 2012.

ROSE, Nikolas \& Peter MILLER. "Political Power beyond the State: Problematics of Government." The British Journal of Sociology 43(2): 173-205. 1992.

SLUKA, Jeffrey A. Reflection on managing danger in fieldwork: dangerous anthropology in Belfast. In: Carolyn Nordstrom e Antonius C. G. M. Robber (orgs). Fieldwork under fire: contemporary studies of violence and survival. Berkeley, Los Angeles, London, University of California Press, 1995.

TILLY, Charles. War Making and State Making as Organized Crime. En P. Evans, D. Rueschemeyer \& T. Skocpol (Eds.), Bringing the State Back In. Cambridge: Cambridge University Press. Pp. 169-191. 1985.

VALLADARES, Licia do Prado. A Invenção da Favela: Do Mito de Origem a favela.com. Rio de Janeiro, Editora FGV, 2005.

Recebido em: 26/03/2015

Aprovado em: 11/06/2015 